AperTO - Archivio Istituzionale Open Access dell'Università di Torino

\title{
Geological map of the upper Pellice Valley (Italian Western Alps)
}

\section{This is the author's manuscript}

Original Citation:

Availability:

This version is available http://hdl.handle.net/2318/91475

since

Published version:

DOI:10.4113/jom.2011.1213

Terms of use:

Open Access

Anyone can freely access the full text of works made available as "Open Access". Works made available under a Creative Commons license can be used according to the terms and conditions of said license. Use of all other works requires consent of the right holder (author or publisher) if not exempted from copyright protection by the applicable law. 


\section{(8) \\ UNIVERSITÀ DEGLI STUDI DI TORINO}

This is an author version of the contribution published on:

Questa è la versione dell'autore dell'opera:

[Journal of maps, 2011, doi:10.4113/jom.2011.1213]

ovvero [Gianni Balestro, Gianfranco Fioraso and Bruno Lombardo, 2011, pagg. 634654]

The definitive version is available at:

La versione definitiva è disponibile alla URL:

[http://www.journalofmaps.com/] 


\section{Geological map of the upper Pellice Valley (Italian Western Alps)}

Gianni Balestro

Dipartimento di Scienze della Terra, Università degli Studi di Torino, Via Valperga Caluso 35, 10125 Torino, Italy;

gianni.balestro@unito.it

Gianfranco Fioraso

Istituto di Geoscienze e Georisorse, Consiglio Nazionale delle Ricerche, Via Valperga Caluso 35, 10125

Torino, Italy;

g.fioraso@csg.to.cnr.it

Bruno Lombardo

Istituto di Geoscienze e Georisorse, Consiglio Nazionale delle Ricerche, Via Valperga Caluso 35, 10125

Torino, Italy;

bruno.lombardo@unito.it 


\section{Abstract}

The 1:25,000 scale geological map of the upper Pellice Valley (Italian Western Alps) encompasses an area of roughly $60 \mathrm{Km}^{2}$ where a composite stack of both oceanic and continental Alpine units crops out. The four units distinguished in the map correspond, from bottom to top, to the Dora Maira Unit, a slice of the Paleozoic European crust, the Giulian-Sea Bianca Unit, a succession of Triassic to Lower Jurassic carbonate metasediments, the Monviso Unit, an ophiolitic remnant of the Mesozoic Tethyan Ocean, and the BucieSeilliere Unit, a carbonate metasedimentary succession of Upper Jurassic to Upper Cretaceous age. Each Unit is bounded by syn-metamorphic faults (i.e. tectonic contacts) and is displaced by a post-metamorphic fault network, then discontinuously covered by heterogeneous alluvial, gravitative, glacial and periglacial Quaternary deposits. The map gives new and updated information about the structural and geological setting of the Pellice Valley through a detailed representation of the main lithological, structural and morphological features. 


\section{Introduction}

The Pellice Valley is part of the Cottian Alps, the central sector of the Italian Western Alps. It is about $20 \mathrm{~km}$ in length and borders with the French Queyras region to the west, the Germanasca Valley to the north and the Po Valley to the south. The Pellice Valley is characterized by a composite stack of both oceanic and continental crust units. In the upper part of the valley, where the Pellice river is north-south oriented, the Monviso Unit (Lombardo et al., 1978; Schwartz et al., 2000), one of the largest remnants of the Mesozoic Tethyan oceanic crust and mantle in the Western Alps, crops out. It is tectonically superposed on a unit of Mesozoic carbonate metasediments overlying the Dora Maira Unit (Vialon, 1966; Sandrone et al., 1993). The latter is a slice of the Paleozoic crust of the European continental margin involved in the Alpine accretionary complex (Polino et al., 1990). The Monviso Unit is tectonically overlain by a Mesozoic succession of Tethyan Ocean origin (the "Schistes Lustrès" of Alpine geological literature; Lemoine and Tricart, 1986; Lagabrielle and Polino, 1988).

The geology of the Pellice Valley was first mapped at the end of the $19^{\text {th }}$ century (Novarese, 1896) and is shown in the Pinerolo sheet of the Geological Map of Italy at 1:100,000 scale (Mattirolo et al., 1913). This map, encompassing the northern part of the Cottian Alps, is not only an historical document but still gives a complete representation of the litostratigraphic features of the area. Modern geological maps of the Pellice Valley are given only on a smaller scale in Sheet 1 of the 1:500,000 Structural Model of Italy (Bigi et al, 1990) and in the geological Sheet 35 "Gap" of the 1:250,000 map of France (Kerckhove et al., 1979), whereas geological maps at larger scales with more detailed structural and lithostratigraphic information, cover only part of the upper Pellice Valley (Lagabrielle and Polino, 1987; Tricart et al., 2003). Structural sketches of the mapped area are shown in Vialon (1966), Zanella and Tissoni (1973), Dal Piaz et al. (1978), Sandrone et al. (1993), Lagabrielle (1994) and Lardeaux et al. (2006).

The aim of the map presented here is to fill the gap of modern geological maps in the Cottian Alps, by giving new and updated information about the lithological, structural and morphological setting of the Pellice Valley area. 


\section{Methodology}

The map at 1:25,000 scale covers an area of roughly $60 \mathrm{Km}^{2}$ that was originally mapped at the 1:10,000 scale. Both the original data and map are represented on a vector topographic map (Carta Tecnica Regionale - vector_50 series; authorization n.15/2010) and stored in a GIS database (Coordinate System WGS 1984 UTM Zone 32N). The overall dataset includes $i$ ) lithological and petrological data collected in three Master's Degree theses (Arduino,1986; Brasher, 1985; Rattalino, 1985), ii) new lithological and structural field information, and iii) new remotely sensed morpho-structural features. The four units distinguished in the map correspond to tectono-stratigraphic units and were classified by the application of tectono-stratigraphic concepts. A tectono-stratigraphic unit is defined as "a rock volume delimited by tectonic boundaries showing a peculiar stratigraphy and/or metamorphic overprint and/or structural arrangement, distinct from the adjoining tectono-stratigraphic units" (Dela Pierre et al., 1997). The interpretation of structural data was based on geometrical analysis (equal-area lower-hemisphere stereographic projections) of the main foliation (principal Surface - Sp) recognizable in rock masses: the Sp allows correlating structural elements and supports the objective identification of those structural elements that were generated before (pre-Sp) or after (post-Sp) in each unit. Two generations of faults were distinguished: syn-metamorphic (ductile) faults (i.e. tectonic contacts), characterized by mylonites indicating intracrystalline plastic deformation, and post-metamorphic (brittle) faults, which are characterized by cataclasites. The morpho-structural analysis was performed by photointerpretation of multitemporal aerial images (1954 black and white 1:55,000-scale photos of the Italian Military Geographic Institute, and 2000 colour 1:25,000-scale photos of the Regione Piemonte). The final map layout, built by a vector graphic editor, includes the raster of the map (GIS-layout), three representative cross-sections, a tectonic sketch map and a geomorphological sketch map.

\section{Lithostratigraphy}


The map includes four units that, from bottom (east) to top (west), correspond to the Dora Maira Unit (DM), the Giulian-Sea Bianca Unit (GS), the Monviso Unit (MO) and the Bucie-Seilliere Unit (BS). Before the description of the different lithostratigraphic and metamorphic features, a short overview of each unit is given in the following.

- The Dora-Maira, one of the "Internal Crystalline Massifs" derived from the European palaeomargin (Vialon, 1966; Michard, 1967; Sandrone et al., 1993), has been formalized as a tectono-metamorphic unit in Sheet 154 Susa of the 1:50.000 Geological Map of Italy (Cadoppi et al., 2002). It has an outcrop surface of more than $2000 \mathrm{~km}^{2}$ extending from the Maira Valley in the south to the Susa Valley in the north, and consists of three sub-units with different Alpine metamorphic histories: 1) the Lower sub-unit, made up of Permian granitoids intruded into blueschist facies monometamorphic sequences; 2) the Upper sub-unit, which underwent eclogite facies metamorphism and is made up of a Variscan polymetamorphic basement, intruded by Late-Paleozoic granites and covered by discontinuous sheets of preserved Mesozoic metasediments; 3) the Coesite-bearing ultra-highpressure sub-unit, made up of polymetamorphic metasediments and Late Paleozoic granites, which crops out in the southern part of the DM and is tectonically wedged between the Lower and the Upper sub-units.

- The Giulian-Sea Bianca Unit is a succession of carbonate metasediments, tectonically interposed between the DM and the MO Units, and named "Giulian-Sea Bianca" referring to the two localities limiting its extension to the south (Punta Sea Bianca; Figure 1a) and to the north (Colle Giulian; Figure 1c). It thickens southward in the Po and the Varaita valleys, where it is assumed to be of Triassic to Liassic age and interpreted as a pre-ophiolitic basal complex (Piemonte external Units; Elter, 1971; Dal Piaz et al., 1978) possibly deposited on the southern DM Unit (Michard, 1967).

- The Monviso Unit is a portion of the Jurassic Tethyan oceanic lithosphere, tectonically superposed on the GS and the DM Units. It thickens southward (from $1 \mathrm{~km}$ in the northern part of the upper Pellice Valley to roughly $3.5 \mathrm{~km}$ in the southern part) and extends from the Germanasca Valley through the Pellice and Po valleys. The MO belongs to the eclogite facies Piemonte Units (the Zermatt-Saas Zone; 
Bearth, 1967) and consists of serpentinites, gabbro- and basalt-deriving metabasites, and of slivers of their metasedimentary cover. It is also indicated as "Monviso Ophiolitic Complex" because of the different stratigraphic (Lombardo et al, 1978) and metamorphic (Schwartz et al., 2000) imbricated sub-units which characterize its inner structure.

- The Bucie-Seilliere Unit belongs to the blueschist/greenschist facies Piemonte Units (Combin Zone: Bearth, 1967; Dal Piaz, 1974) and is a carbonate metasedimentary succession of supposed OxfordianKimmeridgian to Late Cretaceous age (Lemoine and Tricart, 1986) which tectonically overlies the MO Unit. It is here named "Bucie-Seilliere" as this refers to the two localities that bound to the south (Colle Seilliere; Figure 1b) and to the north (Bric Bucie; Figure 1c) its outcrop in the Pellice Valley, but it spreads south and west into the French Queyras region (the Queyras Schistes Lustrés Unit; Tricart et al., 2003), and north into the Germanasca Valley (the Albergian Unit; Dela Pierre et al., 2002). The BS metasediments enclose Jurassic ophiolitic bodies and are interpreted as syn-orogenic deposits of both distal continental margin and trench paleogeographic pertinence (Lagabrielle and Polino, 1988).

\subsection{The Dora-Maira Unit}

The top of the DM Unit, mapped from the Colle Giulian to the Grange della Gianna, consists of Paleozoic metasediments and metagranitoids, locally preserving remnants of their Mesozoic cover. These rocks belong to the Upper sub-unit of the DM. The Paleozoic metasediments (Dm) include garnet- and chloritoidbearing medium-grained micaschists and fine-grained paragneisses, with different contents of quartz, white mica, albite, chlorite and epidote. They are interpreted as a polymetamorphic basement (Sandrone et al., 1993) because of the presence of muscovite, garnet and staurolite relics likely crystallized in the Variscan amphibolite facies metamorphism. Such relics were not directly observed in the investigated area because of the strong overprint of the Alpine high-pressure metamorphism (phengite, garnet, chloritoid and rutile assemblages) and of the subsequent greenschist facies metamorphism. The micaschists contain up to 10-20 meters thick lenticular bodies of metabasites (Dma) (north and south of the Eyssard locality, Alpe La Rossa) of probable basaltic origin (Sandrone et al, 1993). The metabasites have a fine-grained banded texture and 
are mainly made up of actinolite, epidote, clinozoisite, chlorite, albite and green biotite, although garnetand glaucophane-bearing high pressure assemblages are locally well-preserved (Alpe La Rossa).

The Paleozoic metagranitoids intruding the polymetamorphic basement are medium- to coarse-grained orthogneisses (Dg) and subordinate fine-grained leucocratic gneiss (Grange della Gianna). Close to the tectonic contact with the overlying GS Unit, the augen texture is poorly preserved and the orthogneisses are partly transformed into fine-grained mylonitic gneisses.

The Mesozoic cover is preserved in discontinuous slices occurring along the tectonic contact between the GS and DM Units (south of the Eyssard locality, Colle Giulian, Burfaran, Alpe La Rossa, Grange della Gianna). The cover rocks (Dq) consist of up to 5-10 m thick paragneiss and quartzite with decimeter-sized levels of yellowish marble and carbonate micaschist. The quartzite marks the contact with the basement rocks and the Mesozoic succession is, on the whole, similar to the Early Triassic basal part of successions overlying the Paleozoic rocks in the northern sector of the DM (Cadoppi and Tallone, 1992).

\subsection{The Giulian-Sea Bianca Unit}

The GS Unit is a 600 to 900 meter thick metasedimentary carbonate-rich succession interposed between the DM and MO Units. It mainly consists of medium-grained calcschists $(\mathbf{G c})$, that can be considered homogeneous at the map scale despite their continuous variations from carbonate-poor- to carbonate-rich micaschists and greyish fine-grained micaceous marbles. This alternation is, for instance, well exposed in the Colletta delle Faure area, where the calcschists contain lens-shaped carbonate bodies (up to $10 \mathrm{~m}$ thick) and a continuous level (up to $25 \mathrm{~m}$ thick) of medium-grained garnet-bearing micaschist (Gm). The top of the succession is characterized by the presence of meter-sized lenticular bodies of metabasite (Gca) within the calcschists (Monte Giulian, north of Colletta delle Faure, north-west and south-west of Alpe La Rossa, north of Grange del Pis). The metabasites show a banded texture and are mainly made up of greenschist facies minerals. 
In the upper part of the calcschist succession, a notable feature of the GS Unit is the presence of carbonate bodies (Gd) corresponding to fine-grained white dolostone, light-grey dolomite marble and dark-grey marble. The main carbonate body is up to $200 \mathrm{~m}$ thick and $2.5 \mathrm{~km}$ in length from Rocca Bianca to Punta Sea Bianca. Two smaller decameter-sized bodies, about 20-30 m thick, crop out at the Monte Content and north of the Colletta delle Faure. These carbonate bodies are characterized by both transitional and sharp contacts with the surrounding calcschists, and can be broadly interpreted as carbonate platform blocks originally embedded in a slope succession.

\subsection{The Monviso Unit}

The MO Unit is well exposed along the mountain ridge dividing the upper Pellice Valley to the west from the Ghicciard River valley to the east; it mainly consists of serpentinites and metabasites, with minor bodies of metagabbros.

\section{Serpentinites}

Medium-grained antigorite serpentinite and fine-grained antigorite-schist (Ms) mark the contact between the MO Unit and the underlying GS Unit. These rocks consist of antigorite and magnetite, with subordinate brucite, Mg-chlorite, tremolite, diopside, Ti-clinohumite, haematite and (locally) porphyroblasts of metamorphic olivine. The mantle peridotite mineral assemblage is generally not preserved but some textural relics of clinopyroxene, orthopyroxene and spinel are preserved in the more massive serpentinites, whereas in shear zones serpentinites are transformed into mylonitic antigorite- talc- tremolite-schists. The serpentinites are characterized by the presence of meter-sized rodingite dykes (Msa) (Passo Dar Loup, Colle del Baracun, Colle della Gianna, Rocca Nera, Villanova locality) mainly consisting of grossular garnet, chlorite, epidote and diopside. Locally grossular represents about 70\% of the rock (Colle della Gianna), whereas rodingitized pegmatitic metagabbros, with centimeter-sized porphyroclasts of re-equilibrated magmatic clinopyroxene are preserved near the Rocca Nera and the Passo Dar Loup. 


\section{Metagabbros}

Two types of metaintrusives were found in the mapped area, both as meter- to decameter-sized bodies in the serpentinites and as independent bodies: Mg-Al metagabbros and Fe-metagabbros. The mediumgrained Mg-Al metagabbros (Mg) mainly consist of greenschist-facies minerals (albite, zoisite, clinozoisite, actinolite and tremolite) and the magmatic fabric is in general poorly preserved. High-pressure mineral assemblages are only observed in "smaragdite"-bearing Mg-Al metagabbros (Mga) (Passo Dar Loup and east of Monte Manzol) mainly consisting of omphacite pseudomorphs after magmatic clinopyroxene, and of tremolite-actinolite, albite, Mg-chlorite and clinozoisite. The Fe-metagabbros (Me) are fine- to mediumgrained and mainly made up of eclogite-facies assemblages consisting of omphacite pseudomorphs after clinopyroxene, omphacite associated with garnet in pseudomorphs after plagioclase, rutile with later ilmenite and titanite in pseudomorphs after ilmenomagnetite. Eclogites, devoid of relics of the parent Femetagabbros, tipically occur at the Villanova locality and south-west of Alpe La Rossa, where they are in primary association with a large body of Mg-Al metagabbro and well preserve the high-pressure mineralogy (garnet, omphacite, rutile). In some localities (east of the Colle della Gianna, east of Monte Manzol, Lago Piena Sia), the Fe-metagabbros show a pegmatitic texture and are characterized by well-preserved plagioclase-clinopyroxene igneous sites, as already noted by Novarese (1896). A meter-sized body of metaleucogabbro with greenschist-facies mineralogy occurs in the Fe-metagabbros cropping out east of Monte Manzol.

\section{Metabasites}

These rocks (Mb) continuously crop out from Monte Granero in the south to Punta Fiunira in the north, and mark the contact with the overlying BS Unit. They are characterized by a banded texture with epidote-rich levels and tremolite-actinolite-rich levels, with associated albite, clinozoisite and chlorite. High-pressure assemblages are only rarely preserved (glaucophane and garnet relics; Monte Manzol, Colle Pourcel, Colle del Baracun), whereas the greenschist facies minerals (albite, chlorite, tremolite-actinolite, clinozoisite, titanite, epidote and green biotite) are locally well-developed (Colle Bancet, Colletta delle Faure, Colle 
Manzol). The magmatic fabric is generally poorly-preserved but some textural relics of pillow lavas and breccias (Rocca Capus) indicate a volcanic protolith.

\section{Metasedimentary rocks}

The metabasites are associated with different metasedimentary successions that discontinuously crop out at the top of the MO unit and between the metabasites and the underlying serpentinites. The metasedimentary rocks (Mc) correspond to medium-grained calcschists with textural relics of lawsonite (totally replaced by white mica, chlorite and epidote) associated to micaceous marbles and quartz-rich chloritoid-bearing micaschists. Peculiar features of these successions are the occurrence of decimeter- to meter-sized blocks of metabasites, metagabbros and serpentinites, and of decimeter-sized layers of metabasites deriving from gabbroic sandstones (Colle del Baracun, Mirabuc and Villanova localities; Lagabrielle, 1994). The metasediments are particularly widespread in the Colle del Baracun area (the type locality of the Baracun formation: Lagabrielle, 1994), where blocks of eclogitic Fe-metagabbros, finegrained eclogites (north of Colle del Baracun and Colle della Mait; figure 2a) (Perrone, 1999) and serpentinites are well-exposed within the calcschists. In this area the calcschist succession is characterized by decimeter-sized layers of yellowish marbles (Figure 2a) and by decimeter- to meter-sized coarse-grained layers of gabbroic meta-sandstones (Figure 2b). The latter consist of omphacite clasts in a Mg-chlorite matrix, with subordinate zoisite, clinozoisite, actinolite and rutile. Taking into account the Middle Jurassic age of the ophiolite rocks, the metasediments are considered of Late Jurassic to Early Cretaceous age.

\subsection{The Bucie-Seilliere Unit}

The metasedimentary succession tectonically superposed on the MO Unit (the BS Unit), crops out along the western slope of the upper Pellice Valley and mainly consists of fine-grained calcschists (Bc), locally with ophiolitic bodies. The succession is quite heterogeneous and includes carbonate-bearing phyllitic schists, carbonate-rich schists and micaceous marbles, with different contents of calcite, quartz, white mica, chlorite, epidote and albite. The upper part of the succession is in general more carbonatic than the lower 
part. High-pressure minerals are poorly preserved in this unit and include pseudomorphs on lawsonite and relics of garnet and glaucophane (Schwartz, 2000). The metasedimentary succession also includes meter- to decameter-sized levels of medium-grained micaschists (Bm) (Colle Seilliere, east of the Colle della Croce, north of the Alpe Crosenna).

The upper part of the BS Unit is characterized by the presence of decameter- to hectometer-sized lenticular bodies of metabasites $(\mathbf{B b})$. They are mainly made up of greenschist facies minerals and blueschist minerals are generally poorly preserved (relics of crossite; Bric Bucie). One of the largest bodies forms the Bric Bucie peak and consists of basalt-deriving metabasites (Dal Piaz et al., 1978; Lagabrielle and Polino, 1988) with a metasedimentary cover (Bq) of micaceous quartzites, white marbles and layers of metabasite deriving from gabbroic and basaltic sandstones (Lagabrielle and Polino, 1988; Tricart et al., 2003). Another important body forms the Monte Palavas (Bearth et al., 1975; Lagabrielle, 1982; Arduino, 1986) and consists of wellpreserved gabbroic rocks (Bg) with blueschist and greenschist metamorphic overprinting. The gabbroic rocks include massive and foliated cumulitic olivine- and clinopyroxene-bearing gabbros, gabbronorites, Femetagabbros, leucogabbros and dolerites. Layers of cumulitic peridotites (Bs), several meters to a few tens of meters thick, crop out in the south-west and south-east ridges (Bearth et al., 1975), whereas Femetagabbros (Arduino, 1986) crop out at the foot of the north face. A few meter thick relict metasedimentary cover (Bq) of quartzites, marbles and gabbroic metasandstones (Lagabrielle, 1982) crops out close to the Colle dell'Urina. The bodies of metabasites and metagabbros in the BS Unit can be interpreted as olistoliths emplaced by gravitational processes in the carbonate succession, although a tectonic origin ("Palavas ophiolitic klippe" and "Bric Bucie klippe") has been suggested by some authors for the largest bodies (Dal Piaz et al., 1978, Lagabrielle, 1982; Lagabrielle and Polino, 1988).

\section{Structures and Tectonic setting}




\subsection{Mesoscale tectonic features}

\subsubsection{Folds and Foliations}

The main foliation recognizable in rock masses is the $\mathrm{Sp}$ (principal Surface). Lithological contacts are parallel to this foliation, hence this is the element that allows the distinction of those structural elements that, in each unit, have been generated before (pre-Sp) or after (post-Sp) the main foliation.

The oldest structural element, deformed by syn-Sp folds, is a pre-Sp foliation which is coeval with the high pressure metamorphism and is locally preserved in the more competent rocks. The pre-Sp foliation occurs in the metabasites of the DM Unit (Alpe La Rossa), in the dolostones of the GS Unit north of Colletta delle Faure and south of Alpe La Rossa, in different lithologies of the MO Unit (massive serpentinite near the Colle Dar Loup, metagabbros of the Villanova locality, eclogites of the Colle del Baracun and micaceous marbles near the Truc Pailly), and in the metabasites (Bric Bucie) and metagabbros (Monte Palavas) of the BS Unit.

Syn-Sp folds are tight to isoclinal and appear as transposed cylindrical structures. Fold axes are mainly north and south low angle plunging (Figure 3, a-b-c-d), although scattering of data (Figure 3, e) suggests a more complex deformation pattern, presumably characterized by large-scale non-cylindrical folding. Axial surfaces are mainly west-dipping (Figure 3, a-b-c-d) and weakly re-oriented by post-Sp folding (Figure 3, f). $\mathrm{Sp}$ is defined by the preferred orientation of layer silicates and quartz ribbons, both in the gneissic and in the carbonate rocks, and by a compositional layering (albite-rich levels and amphibole-chlorite-epidote rich levels) in the metabasic rocks; the syn-kinematic development of these mineral assemblages testifies to a decompressional evolution from high pressure conditions to greenschist facies conditions. Analysis of the Sp shows that, although it is in general west-dipping, some differences among different units exist: it mainly dips $45^{\circ}$ to the west in the DM and MO Units (Figure 3, g-i), whereas in the GS and in the BS Units (Figure 3, 
h-I) it dips about $30^{\circ}$ to the west-south-west and west-north-west, respectively. The Sp surfaces are characterized by a stretching lineation that is on average west-dipping.

The $\mathrm{Sp}$ is deformed by open cuspate folds, which are widespread in the less competent rocks (calcschists and micaschists) but are also observable in serpentinites and metabasites. These post-Sp features are associated with a crenulation cleavage that locally is the most pervasive surface and corresponds to the post-Sp foliation. This foliation frequently acts as a slip surface (S-C structures showing both normal and reverse movements) and is not related to widespread syn-kinematic re-crystallization. The post-Sp folds are similar among the different units and are mainly characterized by quite clustered east-dipping axial surfaces (Figure 3, m-n-o-p-r) and sub-horizontal, both north- and south-plunging, axes (Figure 3, m,n,o,p-q).

\subsubsection{Faults}

Two different generations of faults have been distinguished in the mapped area based on the occurrence of two types of fault rocks (mylonites and breccias): syn-metamorphic faults (i.e. tectonic contacts) and postmetamorphic faults, respectively.

Syn-metamorphic faults are characterized by the occurrence of greenschist-facies mylonites, resulting from intracrystalline plastic deformation, which are mainly observable along the contacts between the units. The contact between the GS and DM Units (Alpe La Rossa) consists of low-angle west-dipping mylonitic gneisses (no clear kinematic indicators are displayed); the contact between the GS and MO Units (well-exposed at the Colletta delle Faure, east of the Villanova locality and north-west of Alpe La Rossa) is characterized by mylonitic serpentine schists with steep to moderate west to south-west dipping fault surfaces, mainly showing left-normal movements; the contact between the MO and BS Units (exposed in the Crosenna creek and near the Ciabot del Prà) is marked by chlorite- and talc-bearing mylonitic schists and is characterized by moderately west-dipping fault surfaces whose kinematic indicators (mainly S-C structures) indicate both normal and reverse sense of movement. 
Post-metamorphic faults are characterized by the occurrence of cohesive breccias and gouges resulting from brittle deformation. They mostly correspond to faults that crosscut existing structural features although some slip surfaces result from reactivation of syn-metamorphic faults under cataclastic conditions. Reactivated fault surfaces are steeply to moderately west-dipping, whereas new faults mainly consist of conjugate east-west striking surfaces that dip at moderate to high angles. The kinematic indicators (calcite and quartz slickenfibres) indicate normal to transtensive movement.

\subsection{Map-scale tectonic features}

The main map-scale features are the north-south striking and west-dipping contacts between the tectonostratigraphic units (Figures $1 \mathrm{a}, 1 \mathrm{~b}$ and $1 \mathrm{c}$ ). They correspond to deep-rooted and long-lived synmetamorphic faults that constrain the present-day structural setting.

The fault between the GS and DM Units dips both at moderate angle to the west and at low angle to the south-west, and is deformed by large-scale west-verging post-Sp folds which are well-defined in the fault hanging wall (i.e. the GS Unit) by different orientations of Sp (the main hinge zones are localized in the Burfaran area, north of Alpe La Rossa, and northwest of Grange della Gianna). The kinematics of the fault is not clearly definable in the mapped area but, moving from east to west in the footwall (i.e. the DM Unit), the orientation of the Sp and the lithological contacts turn from low angle east-west striking (outside the mapped area) to moderate north-south striking (along the fault). This geometry suggests the apparent "dome" geometry of the DM (Philippot, 1990), supporting the interpretation of this fault as a ductile normal one (West Dora-Maira Detachment; Tricart et al., 2004).

The contact between the GS and MO Units is a shear zone consisting of steeply to moderately west-dipping faults linked to south-west dipping splays, mainly characterized by normal-left movements. However, the occurrence of both mylonites and breccias suggests a long-lasting polyphase activity. The shear zone presumably bounds at depth the GS Unit, which is interpretable as a slice of detached and transposed Mesozoic sediments wedged between the MO and DM Units. The inner structure of the hanging wall (i.e. 
the MO Unit) is particularly well-defined by alternating metasediments and metabasites in the Colle del Baracun area and around the Villanova locality, where the existence of syn-Sp map-scale folds deformed by west-verging post-Sp folds, would explain the repetition at different structural levels of ophiolitic rocks and their metasedimentary cover.

The contact between the MO and BS Units dips toward the west at moderate angle (from $60^{\circ}$ in the north to $40^{\circ}$ in the south) and is described as a ductile normal fault (West Viso Detachment; Tricart et al., 2004; Ballevre et al., 1990), although its kinematic indicators would suggest a polyphase activity, with reverse movements overprinted by normal ones. This fault separates two units that differ in their structure orientation: in the footwall (i.e. the MO Unit), consisting of eclogite facies rocks that plunge down to estimated depths of $8 \mathrm{~km}$ (Lanza, 1975) and $20 \mathrm{~km}$ (Lardeaux et al., 2006), the Sp surfaces and the lithological contacts are moderately west-dipping, whereas in the hanging wall (i.e. the blueschists facies rocks of the BS Unit) the Sp surfaces mainly dip at low angle to the west-northwest (the orientation of the metabasite bodies in the Crosenna Valley is a map-scale example of this trend).

The syn-metamorphic faults as well as all the tectonic features occurring within each unit are crosscut by post-metamorphic normal to transtensive faults with mainly decameter throws. These faults are arranged in a complex fault network in which four main structures can be detected: 1) the north-northeast dipping normal fault that, along with other linked faults, runs from the Col Bucie to the Villanova and Eyssard localities; 2) the Colle dell'Urina fault (Tricart et al., 2003; Figure 4a) that likely continues in the Colle del Baracun area and appears as a south-southwest dipping normal to transtensive fault; 3 ) the fault near Partia d'Amunt, presumably linked to the Colle dell'Urina fault through the southwest-northeast striking fault localized between Punta Pleng and Alpe La Rossa; 4) the southwest-northeast striking normal fault running from Colle Manzol to Colle Proussera, interpretable as a discontinuous prolongation of the Brèche de Ruine fault (Tricart et al., 2003).

\section{Quaternary deposits and geomorphology}


The upper Pellice Valley is characterized by the widespread occurrence of heterogeneous Quaternary alluvial, gravitative, glacial and periglacial sedimentary deposits.

The alluvial and debris flow (FI1) deposits are mainly localized at the junction of the tributary basins with the main valley bottoms, showing a gently sloping $\left(<20-25^{\circ}\right)$ fan-shaped morphology. Between Ciabot del Prà, to the north, and Partia d'Amunt, to the south, alluvial deposits form a broad intermontane plain, with an estimated maximum thickness of $150-180 \mathrm{~m}$. This fluvial accumulation is due to the damming of the Pellice River by the Colle del Baracun landslide which detached from the right side of the valley (Figure 4b). Alluvial deposits are composed of clast-supported gravelly cobbles and sandy gravels, massive to well stratified, sometimes containing pluridecimetric boulders (debris flow deposits). In some cases (Alpe Crosenna and main valley bottom west of the Eyssard locality) post-glacial alluvial deposits form terraces (FI2) suspended 10-20 $\mathrm{m}$ above the river network.

The talus deposits (TI) are widespread all over the upper Pellice Valley, mainly along the Monte Meidassa Punta Pleng ridge and on the northern slope of Rocca Nera. Talus deposits are present at the base of the steep rock walls within the outcrop areas of metasedimentary (BS Unit) and metaophiolitic (MO Unit) bedrock. They are composed of well-sorted centimetric to decimetric angular fragments and blocks, with a clast-supported framework and with openwork to partially openwork texture. In some cases talus deposits are repeatedly reworked by mass movement processes (debris flow and snow avalanche): the resulting mixed facies (Td) are composed of angular clasts, cobbles and gravels with poor sorting and clast-supported framework, sometimes with partially openwork texture.

Landslides (Ld) are mainly localized within the metaophiolitic bedrock of the MO Unit. They correspond to a variety of mass-movement processes: rock falls (i.e. Monte Palavas and Monte Castellus), complex rock slides (i.e. Col Porsel landslide, extending over an area of $0.68 \mathrm{~km}^{2}$ ), rock flow (i.e. Colle della Gianna landslide) and deep-seated gravitational slope deformations (north and south of the Villanova locality). Landslide deposits are composed of chaotic accumulations of angular blocks with scanty or abundant sandy-silty matrix (rock falls and rock flows respectively) or large loosened portions of bedrock (rock slides). 
All gravitational processes have developed subsequently to the glacial retreat (post-LGM; Last Glacial Maximum), after the debuttressing processes involving rock slopes adjacent to glaciers.

Glacial deposits $(\mathbf{U g})$ are extensively preserved at the head of some tributary valleys (Torrente Cruello and Torrente Crosenna catchments) and within the glacial cirques (western slope of the Monte Meidassa Punta Pleng divide). In many cases glacial till forms impressive (more than 10-15 meters high) lateral or end moraines (i.e. Alpe Giulian, Rifugio Granero and north-western slope of Monte Meidassa; Figure 5a) related to temporary halts in post-LGM glacier retreat. Glacial tills are made up of diamicton with silty-sandy matrix containing faceted, smoothed and striated clasts and boulders (lodgement till) or of chaotic and unsorted angular block accumulations with silty-sandy matrix (ablation till).

Several rock glaciers (Rg1 and Rg2) (23) have been identified in the upper Pellice Valley, some of which (5) are currently active (Figure 5b). Rock glaciers are up to a few hundred meters long (with a maximum of 1 $\mathrm{km}$ for the Rocca Nera rock glacier), 100-300 meters wide and cover an area of less than $0.4 \mathrm{~km}^{2}$. Rock glaciers typically show lobate or tongue-shaped plan morphology with a complex system of transverse arcuate ridges and furrows in the distal areas. They are localized mainly on north-western to north-eastern slopes. Inactive rock glacier fronts are localized between 1,890 and 2,595 m a.s.l., whereas fronts of active rock glaciers (i.e. Monte Palavas and Monte Granero) are located at an elevation of 2,365-2,780 m a.s.l. Active rock glaciers are composed of poorly sorted angular blocks, fine material and interstitial ice. In active rock glaciers the front slope is characterized by a steep gradient $\left(38-45^{\circ}\right)$ and block surfaces are devoid of lichens.

The overall morphology of the upper Pellice Valley is strongly controlled by tectonic structures: the synmetamorphic fault separating the BS and the MO Units influences the N-S trending valley west of the Villanova locality, while the post-metamorphic normal faults affect the drainage pattern between Col Bucie and Colle della Croce. Instead, the anomalous elbow of the main valley close to the Villanova locality is presumably due to a capture phenomena exerted by the Pellice River at the expense of an ancient drainage divide, presumably passing through Punta Fiunira and Punta Pleng. 


\section{Conclusions}

The 1:25,000 scale geological map of the upper Pellice Valley gives new information about the composite stack of Alpine units that characterizes the south-central sector of the Italian Western Alps (the Cottian Alps). Specifically, detailed geological mapping has allowed us to pursue the following main topics:

- compilation of a synthesis of both existing and new data about the lithological, structural and petrological features that characterize the four units of the mapped area;

- accurate localization and characterization of the syn-metamorphic faults that bound the units;

- characterization of the post-metamorphic fault network crosscutting the syn-metamorphic faults and the intra-units tectonic features;

- detailed representation of the Quaternary deposits and of their geomorphological features.

The new and updated geological information about the Pellice Valley may support further interpretations about the geodynamics of the central sector of the Western Alps. The map and its linked GIS database will also be useful for new field investigations in the adjoining areas and, particularly, for a detailed map representation of the southern sector of the MO Unit where a review of its complex inner setting is in progress by the authors.

\section{Software}

The map database was built by ESRI ${ }^{\circledR}$ ArcGIS 9, whereas the final map layout was assembled by Adobe ${ }^{\circledR}$ Illustrator 10. Structural data were plotted by StereoNett. Photos were managed and compiled with Deneba ${ }^{\circledR}$ Canvas 8.

\section{Acknowledgments}


The authors thank C. Riccomini, P. Tartarotti and H. Apps for constructive reviews, and A. Festa, P. Cadoppi and M. Gattiglio for helpful discussions both in the field and in the laboratory.

\section{References}

\section{Figure captions}

Figure 1: a) overview of the Monviso Unit south of the Pellice river taken from the Alpe Giulian toward the divide (white dashed line) with the Po Valley (view looking south); b) view of the tectonic contact between the Monviso and the Bucie-Seilliere Units in the southern sector of the map (photo taken from the Ciabot del Prà; view looking south); c) view of the contacts that bound the four units north of the Pellice river (photo taken from Monte Colletta; view looking north).

Figure 2: a) block of eclogite and layer of yellowish marble within the calcschists of the Monviso Unit (photo taken from Colle del Baracun; view looking north); b) layer of gabbroic meta-sandstone within the calcschists of the Monviso Unit ((photo taken from the Colle del Baracun path, 2,190 m a.s.l., view looking north).

Figure 3: stereographic projections (lower-hemisphere equal-area; $n$ : number of data) of structural features (A: fold axis; PA: poles of axial planes; Sp: poles of main foliation) in each unit and density contouring (contour interval $2 \%$ ) of overall syn-Sp fold data and post-Sp fold data. 
Figure 4: a) view of the Colle dell'Urina fault (red dashed line) taken from Colle del Baracun (view looking west); b) the post-glacial Colle del Baracun landslide dam (red arrow) and accumulation (white dashed line) (photo taken from the Colle della Croce path, 2,192 m a.s.l.; view looking east).

Figure 5: a) the Lago Lungo moraine dam (yellow arrows) which originated from the dumping of debris transported by the Seilliere Glacier (photo taken from the ridge separating the Colle Seilliere and Passo Seillierino, 2,450 m a.s.l.; view looking north); b) the Lago Nero moraine dam which originated from glacial ablation till $(\mathrm{gl})$ with the contribution of an active rock glacier $(\mathrm{rg})$ descending from the northern slope of Monte Granero (photo taken from the Colle Manzol; view looking south-west). 

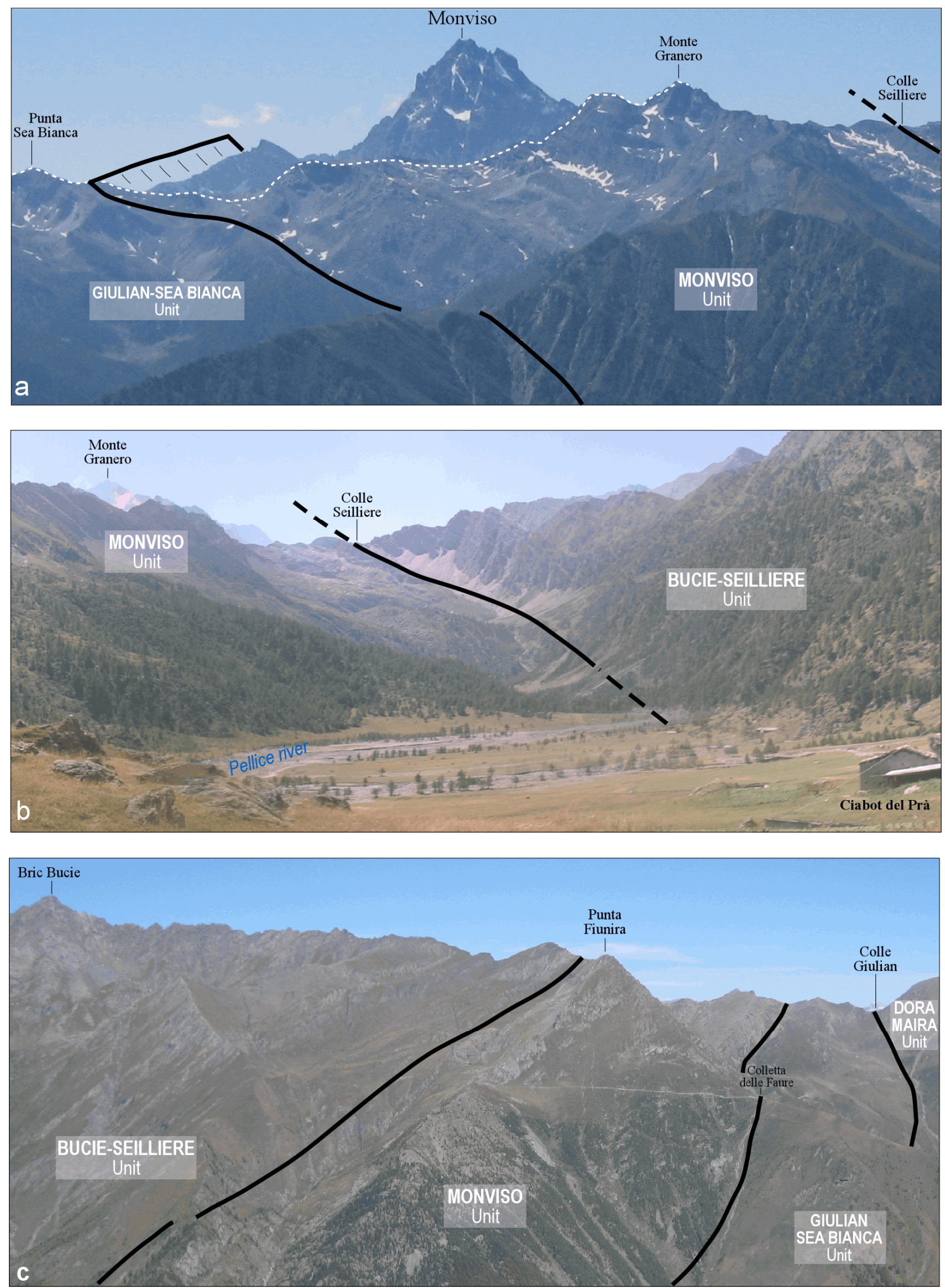

Figure 1 

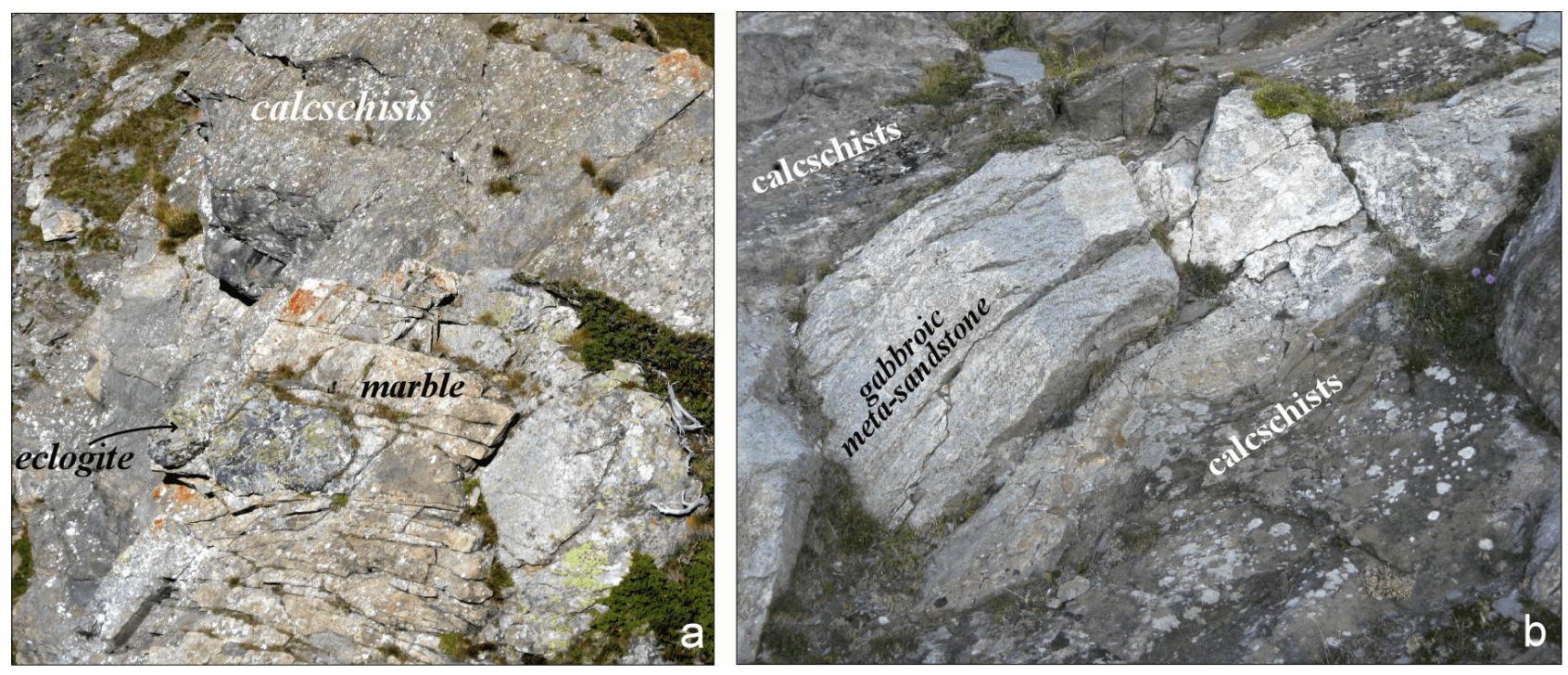

Figure 2 


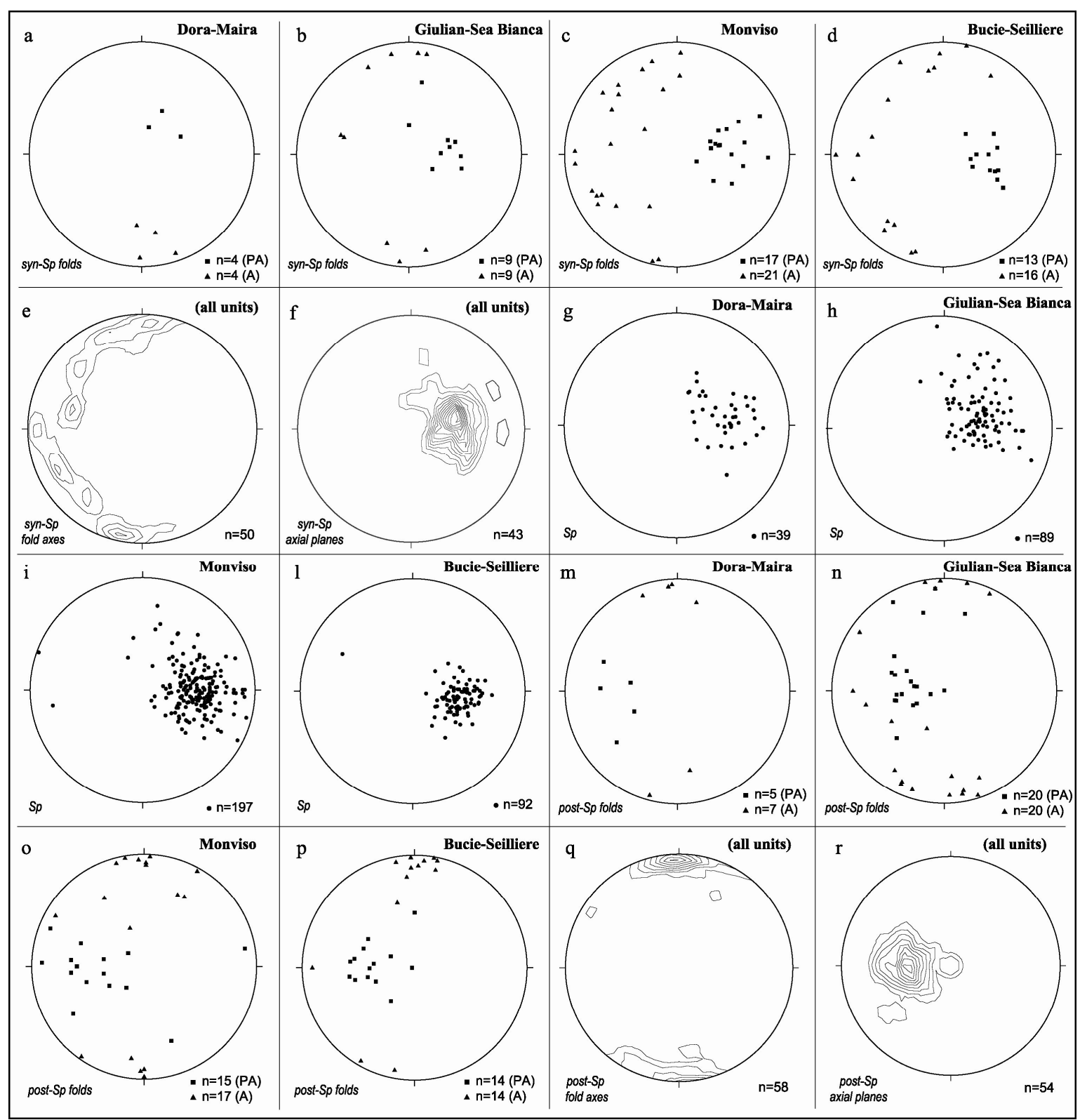

Figure 3 

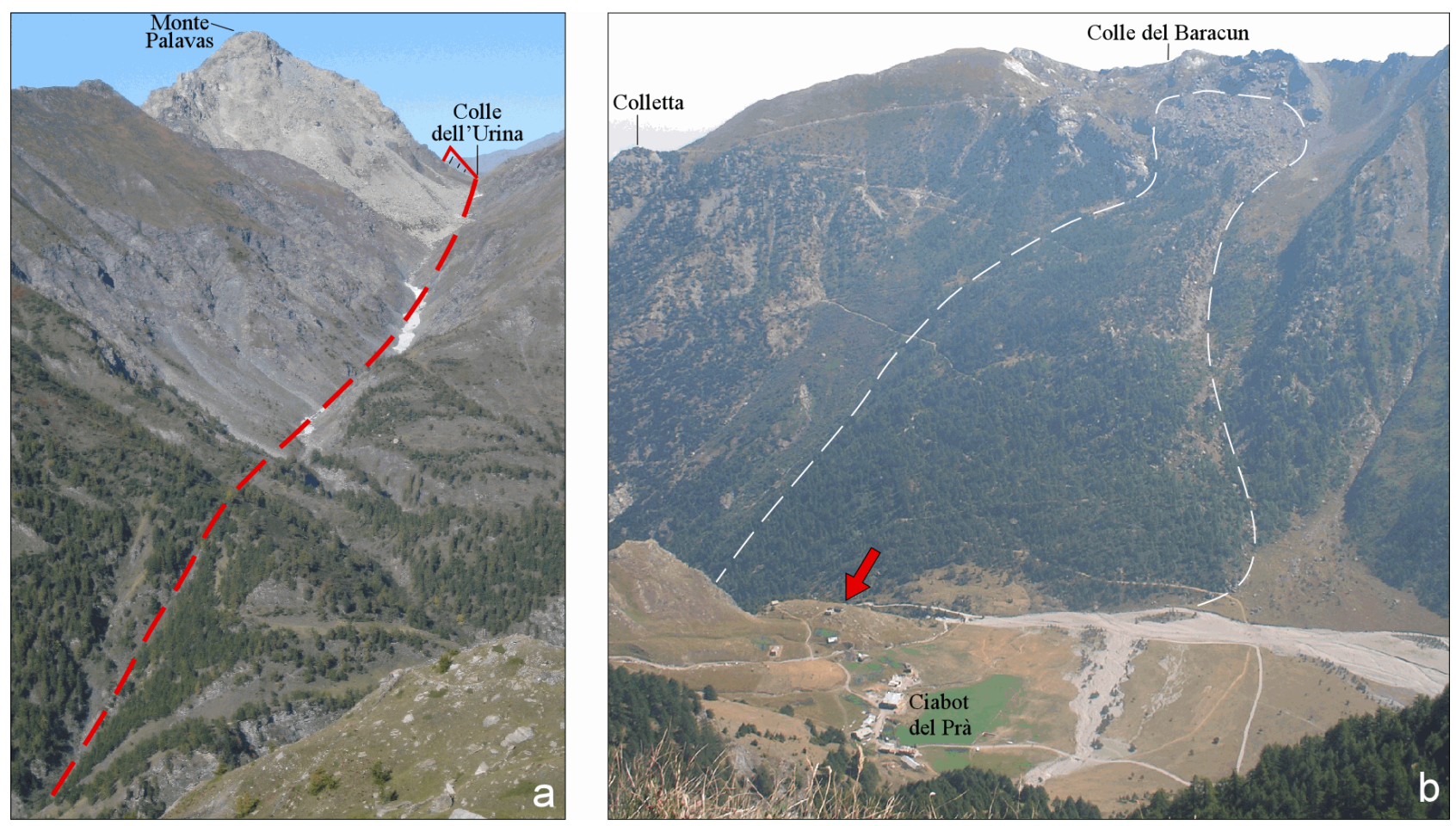

Figure 4 

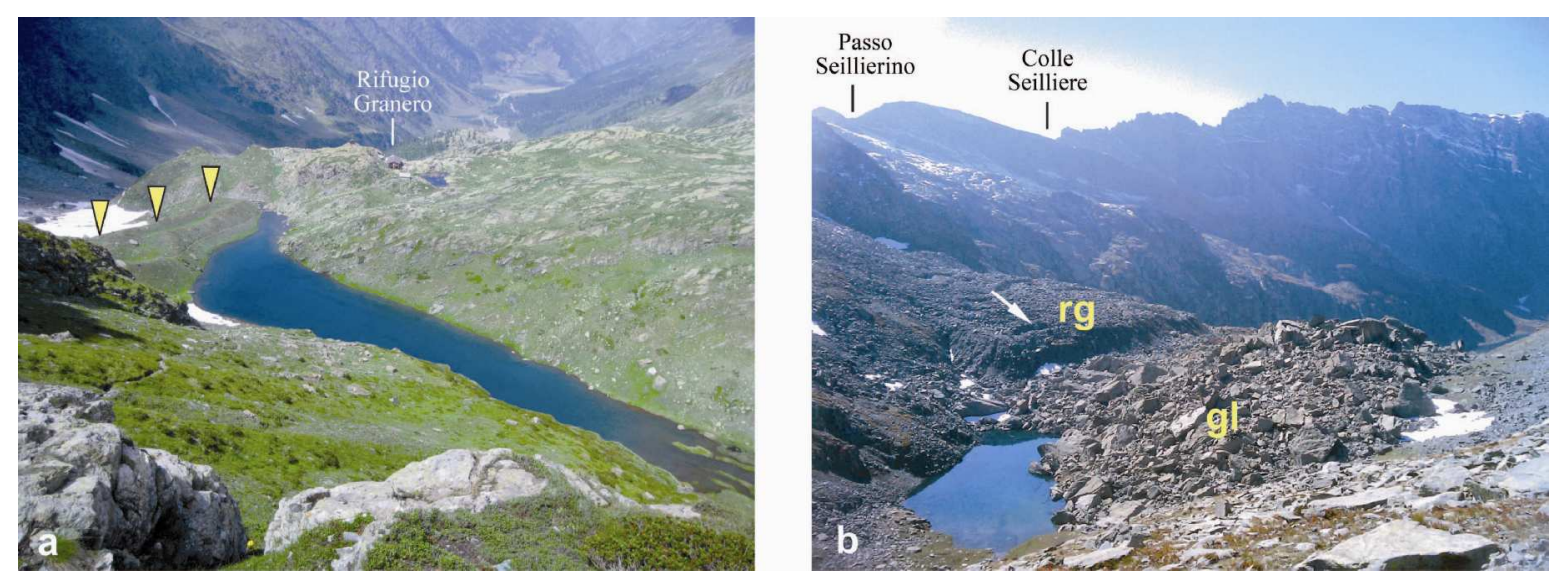

Figure 5 